\title{
Flow cytometric DNA analysis of the haematopoietic tissue of carp Cyprinus carpio during experimental infection with the haemoflagellate Trypanoplasma borreli
}

\author{
Rolf Hamers, Roland Goerlich \\ Institute for Agricultural Botany, Rheinische Friedrich-Wilhelms-Universität Bonn, Meckenheimer Allee 176, \\ D-53115 Bonn, Germany
}

\begin{abstract}
Common carp Cyprinus carpio L. were experimentally infected with the haemoflagellate Trypanoplasma borreli Laveran \& Mesnil, 1901. During parasitemia, proliferation rates of anterior and trunk kidney, spleen and thymus were investigated by flow cytometry using 4,6-diamidino-2phenylindole (DAPI) as DNA dye. It was demonstrated that flow cytometric DNA analysis is a helpful tool for investigating the proliferation behaviour of haematopoletic tissue from infected carp. At the maximum and during the chronic phase of the parasitemia, infected carp showed an increased percentage of S-phase cells in anterior kidney, trunk kidney and thymus compared to non-infected fish. The results indicate that $T$. borreli stmulates poiesis of haematological/immunological tissues in vivo.

KEY WORDS: Carp Blood flagellate - Flow cytometry Kidney proliferation
\end{abstract}

\section{INTRODUCTION}

Flow cytometric DNA analysis is a well-established method for determination of cell cycle stages (Göhde \& Dittrich 1970) as well as measurement of DNA contents of individual cell populations in different organisms, including fish (Allen 1983, Lee et al. 1984, Tiersch et al. 1989, Melamed et al. 1991, Kendall et al. 1992). Nevertheless, there are no data available from cell cycle analysis of haematopoietic tissue in fish during parasitic infection.

The haemoflagellate Trypanoplasma borreli Laveran \& Mesnil, 1901 is a parasite of European cyprinids (Lom 1979). Experimental infection of goldfish Carassius auratus (Lom 1979) and carp Cyprinus carpio fingerlings (Lom et al. 1986) led to high mortalities of the host. Histologically, splenomegalia, oedematous changes in kidney and infiltration of infected tissues by phagocytic cells (Dyková \& Lom 1979, Lom 1979, Lom et al. 1986) were observed. Experimental infection of common carp led to leucocytosis (Steinhagen et al. 1990), especially mono- and lymphocytosis (Hamers 1994a). In the present investigation, flow cytometric DNA analysis was found to be a useful method for determinating proliferation rates of haematopoetic tissue of common carp experimentally infected with $T$. borreli. This technique could also be used for intensively researching the influence of exo- and endogenous pathogens on the proliferation rates in fish tissue.

\section{MATERIAL AND METHODS}

Carp ( 80 to $110 \mathrm{~g}$ ) were obtained from a fish farm near Cologne (Germany) and maintained in aerated aquaria with running water at $20^{\circ} \mathrm{C}$. Fish were fed once a day with commercial fish food. No clinical signs of ectoparasites, endoparasites, or bacterial or viral infections were found, as tested by well-established methods (Amos 1985) ( $n=20$ ). Carp were also tested for trypanoplasm infection 6, 4 and 2 wk before experimental infection using the haematocrit centrifuge technique described by Woo (1969). Only carp without any detectable infection were used in this study. Each 
of 45 carp was experimentally infected by intraperitoneal inoculation with 10000 Trypanoplasma borreli from a strain of cloned parasites as described by Kruse (1985) and Steinhagen (1985). As a control, 10 uninfected carp were used and maintained under the same conditions as the infected fish. At 10, 18, 25, 27, 33, 42, 64,70 and 128 d post infection (p.i.) blood was collected in heparinised plastic tubes (Greiner, Solingen, Germany) from 5 infected carp and 1 control carp by puncturing the heart as described by Lehmann \& Stürenberg (1980). The level of parasitemia was estimated using a haemocytometer

The carp were killed and samples of anterior and trunk kidney, spleen and thymus were taken. Fish (infected and non-infected) were examined for bacterial, viral and other parasitic infection by the Fish Health Service of North Rhine-Westphalia (Germany) using well-established methods (Amos 1985, Bullock \& Bresch 1985, Inglis et al. 1993). Tissue samples were prepared according to the technique described by Otto (1990) and each cell suspension was fixed with $70 \%$ ethanol for $3 \mathrm{~d}$ at $4^{\circ} \mathrm{C}$. Nuclear DNA of the fixed cells was stained with 4,6-diamidino-2-phenylindole (DAPI) (Serva, 18860) as described by Otto (1990). For DNA measurement, a CA II flow cytometer (Partec AG, Münster, Germany) was used with the following filters: KG 1, BG 38 and UG 1; TK 420 as a dichroic mirror; and GG 435 as a barrier filter. Calibration was carried out using a rainbow trout standard (Partec, 06-5-7302).

Each tissue sample was measured in duplicates of $1 \times 10^{6}$ cells. Histograms were analysed with a DPAC computer system (Partec). The number of cells in the $G_{1}, S$ and $G_{2} / M$ phases was expressed as mean \pm $\mathrm{SD}$. Differences in the mean values from infected carp and uninfected controls were evaluated by Student's $t$-test.

For each tissue sample, smear preparations were made and stained with a modified May-GrünwaldGiemsa stain according to Hamers (1995). Additionally, parasites were isolated from kidney and spleen of infected fish as previously described (Hamers 1993) and suspensions of parasites were fixed and stained for DNA analysis as described above. Peripheral blood of non-infected carp was collected in heparinised plastic tubes (Greiner) by puncturing the heart. Cell suspensions (peripheral blood cells, PBC) were fixed and stained as described above. Suspensions of stained Trypanoplasma borreli were mixed with 0, 100, 300 and $500 \mu \mathrm{l}$ of stained PBC.

\section{RESULTS}

No clinical signs of parasitic, bacterial or viral infections were found in control fish. All carp experimen- tally infected with Trypanoplasma borreli developed parasitemias but showed no other signs of bacterial, parasitic or viral infections. At $10 \mathrm{~d}$ p.i. T. borreli was demonstrated in blood samples (100 to $150 \mathrm{~T}$. borreli $\mu \mathrm{l}^{-1}$ blood). Maximum values were recorded at Day 33 p.i., with an average of $8000 \mathrm{~T}$. borreli $\mathrm{Hl}^{-1}$ blood. The following chronic phase (average concentration of 5000 parasites $\mu l^{-1}$ blood) lasted until Day 70 p.i. Parasites were detected from Day 10 p.i. to Day 70 p.i. in smear preparations of all tissues examined, with the exception of the thymus

Samples of isolated Trypanoplasma borreli mixed with carp PBC showed a peak at low levels of DNA content (Fig. 1). Therefore, the presence of parasites in
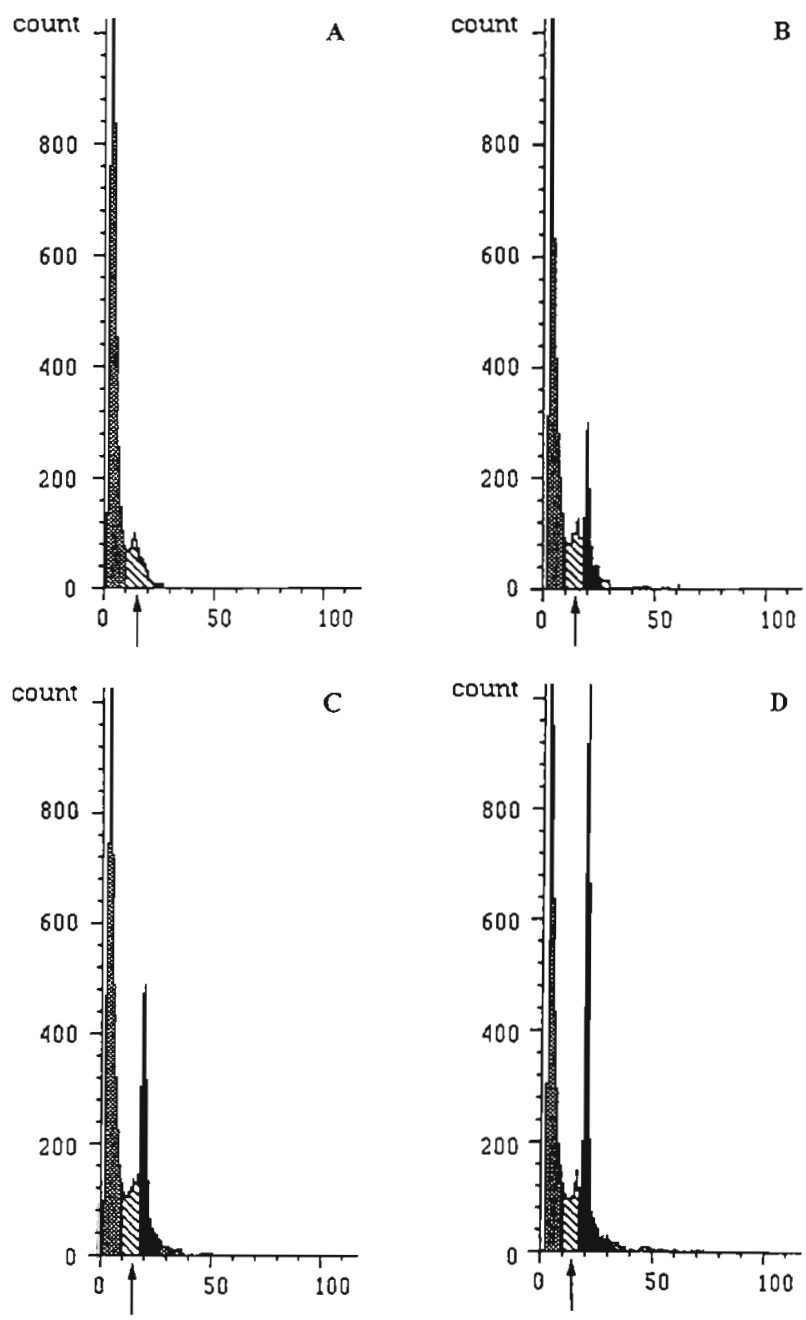

Fig. 1. DNA histograms of Trypanoplasma borreli (arrows) isolated from kidney and spleen of infected carp Cyprinus carpio, mixed with (A) 0, (B) 100, (C) 300 and (D) $500 \mu l$ of peripheral biood cells (black peaks) from uninfected carp. The grey shaded peaks on the left of the histograms represent cell artefacts. The numbers on the $x$-axis represent channel no. (= relative DNA content) 
tissue cell suspensions for DNA analysis has no effect on measurements of tissue cell proliferation.

Fig. 2 shows representative histograms obtained from the anterior kidney of control and infected carp at $33 \mathrm{~d}$ p.i. The percentage of $G_{1}$ - and $G_{2} / M$-phase cells from anterior kidney (pronephros), trunk kidney, spleen and thymus during an experimental infection with Trypanoplasma borreli are given in Table 1. Changes in the percentage of S-phase cells are shown in Fig. 3.

Compared to uninfected controls, in the pronephros a significant increase $(p<0.05)$ in the proportion of S-phase cells [12.14 $\pm 3.27 \%$ (SD), Fig. 3] occurred between 27 and $64 \mathrm{~d}$ p.i. Trunk kidney and spleen showed a significant increase in the percentage of S-phase cells only at Day 42 p.i. $(20.18 \pm 7.18 \%)$ and Day 18 p.i. ( $14.5 \pm 4.23 \%)$, respectively. Although parasites were not detected in smears from the thymus, the proportion of cells in the $S$ phase was also increased in this tissue between 33 and $42 \mathrm{~d}$ p.i. During the maximum and chronic phases of the parasitemia,
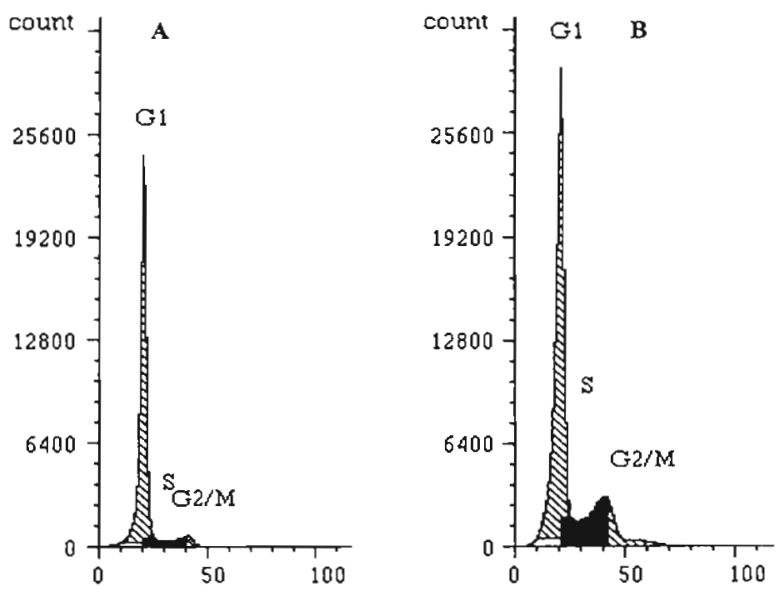

Fig. 2. DNA histograms of anterior kidney from (A) noninfected carp Cyprinus carpio and (B) carp infected with Trypanoplasma borreli ( $33 \mathrm{~d}$ p.i.). For each sample, $10^{6}$ cells were measured. Note the increased proportion of S-phase cells (black area) in (B). Numbers on the $x$-axis represent channel no. (= relative DNA content)
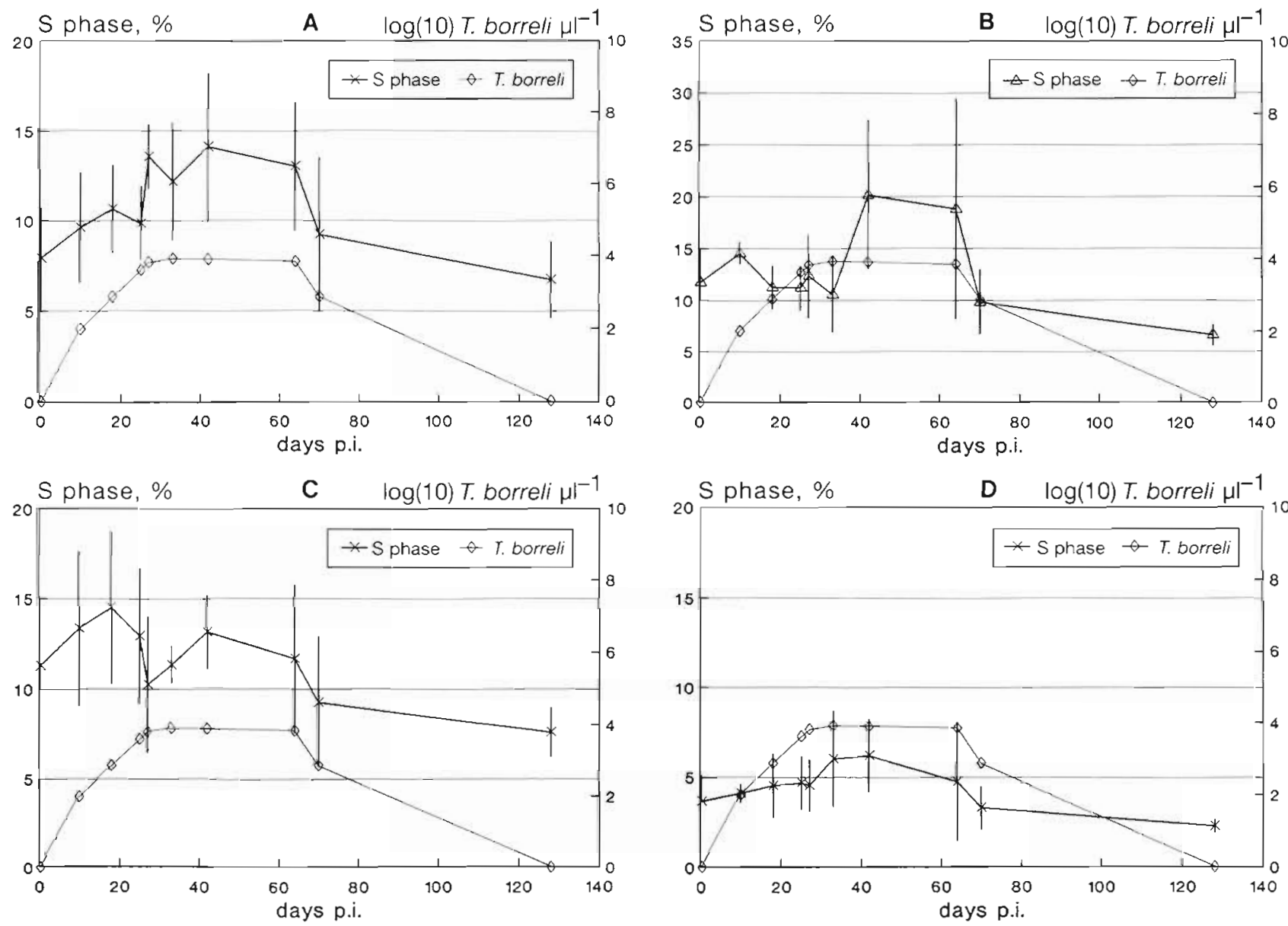

Fig. 3. Changes in the proportion of S-phase cells in tissues of carp Cyprinus carpio, infected with Trypanoplasma borreli. (A) Pronephros, (B) mesonephros, (C) spleen, (D) thymus. Vertical lines indicate standard deviation; thin line shows log(10) $T$. borreli $\mathrm{\mu l}^{-1}$ peripheral blood for each data point $\mathrm{n}=5$ 
blastogenic cells were found in different phases of mitosis in smear preparations of anterior kidney and thymus (Fig. 4)

\section{DISCUSSION}

DNA analysis by flow cytometry has become well established as a method for determining intracellular DNA content (Lee et al. 1984, Allen et al. 1986, Kendall et al. 1992) as well as for the characterisation of individual cell populations (Ellsaesser et al. 1985, Morgan et al. 1903) and apoptosis (Nlford ct al 1994) and for genomic research (Thorgaard et al. 1982, Allen 1983, Johnson et al. 1987, Schreiber et al. 1994). Utter et al. (1983) used flow cytometry for investigating cells from liver, kidney and adipose fin of Pacific salmon.

Although flow cytometry is commonly used to examine the phases $\left(\mathrm{G}_{1}, \mathrm{~S}\right.$ and $\mathrm{G}_{2} / \mathrm{M}$ ) of mammalian tissue cells (Gray et al. 1991 and references cited therein). investigations of the cell-cycle distribution in fish are rarely found in the literature (Utter et al. 1983).

The anterior and trunk kidney of fish are known to be the major haemopoietic organs for granulocyte, Blymphocyte and monocyte differentiation in fish (Zapata 1979, Botham \& Manning 1981), whereas the main
Table 1 Percentage of $\mathrm{G}_{1}$ - and $\mathrm{G}_{2} / \mathrm{M}$-phase cells of anterior and trunk kidney, spleen and thymus of Cyprinus carpio infected with Trypanoplasma borreli (for each sample day, $\mathrm{n}=5$ ); means $\pm \mathrm{SD}$. 0 days p.i. refers to noninfected carp $(n=10)$

\begin{tabular}{|ccccc|}
\hline Days p.i. & Anterior kidney & Trunk kidney & Spleen & Thymus \\
\hline $\mathbf{G}_{\mathbf{I}}$ phase & & & & \\
0 & $88.03 \pm 5.81$ & $84.50 \pm 4.50$ & $86.57 \pm 3.58$ & $95.50 \pm 1.58$ \\
10 & $88.29 \pm 4.55$ & $82.15 \pm 1.41$ & $83.42 \pm 4.68$ & $94.94 \pm 0.66$ \\
18 & $86.40 \pm 3.10$ & $85.30 \pm 3.36$ & $82.40 \pm 5.01$ & $94.40 \pm 1.92$ \\
25 & $87.70 \pm 2.86$ & $85.63 \pm 3.10$ & $83.90 \pm 4.77$ & $94.53 \pm 1.51$ \\
27 & $84.59 \pm 3.11$ & $84.40 \pm 5.41$ & $87.44 \pm 5.66$ & $94.76 \pm 1.37$ \\
33 & $86.40 \pm 5.10$ & $87.54 \pm 4.27$ & $85.00 \pm 3.19$ & $91.54 \pm 3.80$ \\
42 & $82.49 \pm 5.14$ & $75.21 \pm 8.89$ & $83.30 \pm 2.62$ & $92.46 \pm 2.47$ \\
64 & $83.81 \pm 4.49$ & $77.41 \pm 12.93$ & $84.56 \pm 3.89$ & $94.38 \pm 3.42$ \\
70 & $88.80 \pm 5.08$ & $88.00 \pm 3.65$ & $88.32 \pm 4.45$ & $95.78 \pm 1.22$ \\
128 & $91.80 \pm 4.32$ & $91.68 \pm 1.38$ & $90.63 \pm 2.24$ & $96.65 \pm 0.42$ \\
$\mathbf{G}_{2} \mathbf{M}$ M phase & & & & \\
0 & $2.05 \pm 1.13$ & $3.17 \pm 1.23$ & $3.16 \pm 1.34$ & $0.95 \pm 0.42$ \\
10 & $2.11 \pm 1.55$ & $3.37 \pm 1.06$ & $3.24 \pm 1.13$ & $0.97 \pm 0.13$ \\
18 & $3.01 \pm 0.99$ & $3.56 \pm 1.31$ & $3.20 \pm 1.61$ & $1.10 \pm 0.34$ \\
25 & $2.50 \pm 0.99$ & $3.22 \pm 1.09$ & $3.08 \pm 1.67$ & $0.83 \pm 0.45$ \\
27 & $2.88 \pm 0.75$ & $3.32 \pm 1.47$ & $2.34 \pm 1.94$ & $0.73 \pm 0.16$ \\
33 & $1.75 \pm 1.31$ & $1.96 \pm 0.81$ & $3.72 \pm 2.18$ & $3.30 \pm 0.24$ \\
42 & $3.42 \pm 1.08$ & $4.62 \pm 1.70$ & $3.58 \pm 0.65$ & $1.37 \pm 0.57$ \\
64 & $3.20 \pm 0.91$ & $3.71 \pm 2.24$ & $3.76 \pm 0.19$ & $0.90 \pm 0.13$ \\
70 & $2.00 \pm 0.91$ & $2.33 \pm 1.02$ & $2.44 \pm 1.20$ & $0.96 \pm 0.21$ \\
128 & $1.51 \pm 0.57$ & $1.65 \pm 0.39$ & $2.26 \pm 0.15$ & $1.11 \pm 0.51$ \\
& & & & \\
& & & & \\
& & & &
\end{tabular}

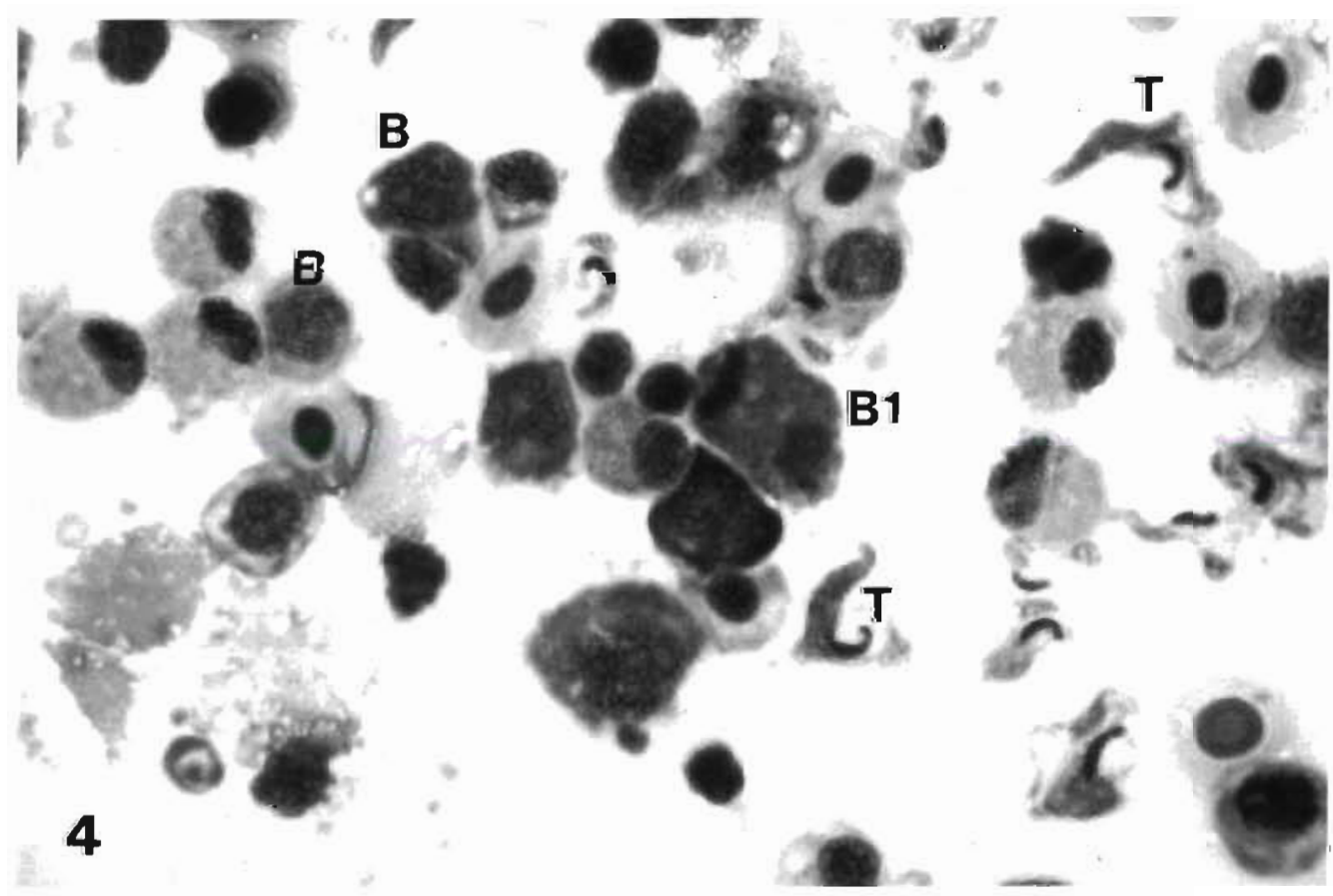

role of the spleen is erythropoiesis (Rowley et al. 1988). The fish thymus can be regarded as a major lymphoid organ for T-lymphocytes (Chilmonczyk 1992). After hatching, the thymus shows increased mitotic activity compared to other organs (Ellis 1988), and its maximum development is reached during the following
Fig. 4. Smear preparation of anterior kidney from carp Cyprinus carpio infected with Trypanoplasma borreli ( $33 \mathrm{~d}$ p.i.) May-Grünwald-Giemsa stain. Blastogenic cells (B) and T borreli (T) can be seen. The cell labelled $B 1$ is in the anaphase stage of mitosis. $(\times 630)$ 
weeks and months (Chilmonczyk 1992). Therefore, changes of proliferation rates in the haemo- and immunopoietic organs of fish may reflect alterations of the cellular defense system due to exo- and/or endogenous pathogens such as bacteria, virus and parasites.

The present investigation has shown that flow cytometric DNA analysis using DAPI as the DNA dye is a reliable method for measurement of cell proliferation within haematopoietic organs in fish.

It has been reported that Trypanoplasma borreli infection in carp leads to splenomegaly and leucocytosis (Dyková \& Lom 1979, Lom 1979, Lom et al. 1986, Steinhagen et al. 1990). The leucocytosis observed during $T$. borreli infection results from mono- and lymphocytosis (Hamers 1994a). Monocytosis can be related to enhanced monopoesis in anterior or/and trunk kidney, whereas lymphocytosis reflects an increase of the proliferation rates in kidney or/and thymus.

For the examination of proliferating cells in tissues which contain numerous xenogeneic cells (e.g. parasites, bacteria), these xenogeneic cells must be eliminated. In Trypanoplasma borreli infected carp, however, this was not a problem, since the parasites and host cells contained different amounts of DNA (Fig 1). Therefore, we assume that in our experiments only proliferating cells of the host's kidney and spleen tissues were measured and that elimination of the parasites was not required.

The results show that Trypanoplasma borreli can induce an increased proliferation of cells from the main haematopoietic tissues (anterior kidney and thymus) in carp. The significant increase in the proliferation rate of cells from the anterior kidney indicates that this tissue is the major argan for poiesis of monocytes and B-lymphocytes in carp during $T$. borreli infection. In contrast to this, it appears likely that poiesis of $T$ lymphocytes is primarily based on the increased proliferation rates of the thymus at the maximum of infection. As a result of the increased proliferation activity in haematopoietic tissues during $T$. borreli infection, an enhanced release of monocytes and lymphocytes into peripheral blood might occur, resulting in leucocytosis and monocytosis, as recently demonstrated by Hamers (1994a).

Carp infected with Trypanoplasma borreli produce parasite-specific antibodies (Jones et al. 1993). Unspecific cellular defense mechanisms, such as phagocytosis by monocytes/macrophages, also play an im. portant role in the elimination of this pathogen and have often been described in the literature (Dykovà \& Lom 1979, Lom et al. 1986, Lom \& Dykovà 1992, Hamers 1994a).

Besides inducing a proliferation of cells in haematopoietic tissue of carp in vivo as described in this paper, Trypanoplasma borreli has also been shown to induce a proliferation of leucocytes in vitro (Hamers $1994 b)$.

Acknowledgements. We are grateful to Prof. Dr J Lehmann and Mr F.-J. Stürenberg (Landesanstalt für Ökologie, Bodenordnung und Forsten, Kirchhundem, Germany) for their scientific support and their critıcal comments. This study was supported in part by the Deutsche Forschungsgemeinschaft (Germany).

\section{LITERATURE CITED}

Altord PB, Tomasso JR, Bodine AB, Kendall C (1994) Apoptotic death of peripheral leucocytes in channel catfish: effect of confinement-induced stress. J aquat Anim Health $6: 64-69$

Allen SK (1983) Flow cytometry: assaying experimental polyploid fish and shellfish. Aquaculture 33:317-328

Allen SK, Thiery RG, Hagstrom NT (1986) Cytological evaluation of the likelihood that triploid grass carp will reproduce. Trans Am Fish Soc 115:838-840

Amos $\mathrm{KH}$ (1985) Procedures for the detection and identification of certain fish pathogens, 3rd edn. Fish Health Section, American Fisheries Society, Corvallis, OR

Botham JW, Manning MJ (1981) The histogenesis of the lymphoid organs in the carp Cyprinus carpio L. and the ontogenetic development of allograft reactivity. J Fish Biol 19:403-414

Bullock AM, Bresch H (1985) Labor-Methoden. In: Roberts RJ (ed) Grundlagen der Fischpathologie. Paul Parey, Berlin, p 324-361

Chilmonczyk S (1992) The thymus in fish: development and possible function in the immune response. A Rev Fish Dis 2:181-200

Dyková I, Lom J (1979) Histopathological changes in Trypanoplasma danilewskyi Laveran \& Mesnil, 1904 and Try. panoplasma borreli Laveran \& Mesnil, 1901 infections of goldfish, Carassius auratus (L.). J Fish Dis 2:381-390

Ellis AE (1988) Ontogeny of the immune system in teleost fish. In: Ellis AE (ed) Fish vaccination. Academic Press, London, p 20-31

Ellsaesser CF, Miller NW, Cuchens MA, Lobb CJ, Clem LW (1985) Analysis of channel catfish peripheral blood leucocytes by bright-field microscopy and flow cytometry. Trans Am Fish Soc 114:279-285

Göhde W, Dittrich W (1970) Simultaneous pulse cytofluorometric analysis of cell cycle distributions using propidium iodide. J analyt Chem 252:328-330

Gray JW, Dolbeare F, Pallavicini MG (1991) Quantitative cellcycle analysis. In: Melamed MR, Lindmo RT, Mendelsohn ML (eds) Flow cytometry and sorting, 2nd edn. Wiley-Liss, New York, p 445-468

Hamers R (1993) Isolation of Trypanoplasma borreli Laveran and Mesnil, 1901, from tissue of infected carp Cyprinus carpio. Bull Eur Ass Fish Pathol 13(6):199-200

Hamers R (1994a) Untersuchungen zur Hämatologie und Immunologie des Karpfens (Cyprinus carpio L.) bei Infektionen durch Blutflagellaten. Dissertation, RuhrUniversität Bochum, Fachbereich Biologie

Hamers R (1994b) Studies on carp lymphoid cells from kidney, peripheral blood and spleen stimulated in vitro with blood parasites and superantigen. Bull Eur Ass Fish Pathol 14(6): $191-194$ 
Hamers R (1995) Granulation staining and cytochemistry of peripheral blood cells of healthy carp (Cyprinus carpio L.) I. Granulocytes. J appl Ichthyol 11:86-93

Inglis V, Roberts RJ, Bromage NI (1993) Bacterial discascs of fish. Blackwell Scientific Publications, Edinburgh

Johnson OW, Utter FM, Rabinovitch PS (1987) Interspecies differences in salmonid cellular DNA identified by flow cytometry. Copeia 1987:1001-1009

Jones SRM, Palmen M, Van Muiswinkel WB (1993) Effects of inoculum route and dose on the immune response of common carp, Cyprinus carpio to the blood parasite Trypanoplasma borreli. Vet Immunol Immunopathol 36:369-378

Kendall C, Valentino S, Bodine AB, Luer CA (1992) Flow cytometric DNA analysis of nurse shark, Ginglymostoma cirratum (Bonaterre) and clearnose skate, Raja eglanteria (Bosc) peripheral red blood cells. J Fish Biol 14:123-129

Kruse $P$ (1985) Untersuchungen zur Artdiagnose und zum Entwicklungszyklus von Trypanoplasma borreli Laveran \& Mesnil, 1901 im Karpfen (Cyprinus carpio L.) und im Egel (Piscicola geometra L.). Dissertation, Universität Hannover, Fachbereich Biologie

Lee GM, Thornthwaite JT, Rasch EM (1984) Picogram per cell determination of DNA by flow cytofluorometry. Analyt Biochem 137:221-226

Lehmann J, Stürenberg FJ (1980) Techniken zur Blutentnahme bei Süßwassernutzfischen. Fisch Umwelt 8:77-88

Lom J (1979) Biology of trypanosomes and trypanoplasms of fish. In: Lumsden WHR, Evans DA (eds) Biology of the Kinetoplastida, Vol 2. Academic Press, London, p 269-337

Lom J, Dyková I (1992) Protozoan parasites of fish. Developments in aquaculture and fisheries science 26. Elsevier Amsterdam

Lom J, Dyková I, Macháchová B (1986) Experimental evidence of pathogenicity of Trypanoplasma borreli and Trypanosoma danilewskyi for carp fingerlings. Bull Eur Ass Fish Pathol 6:87-88

Melamed MR, Lindmo T, Mendelsohn ML (eds) (1991) Flow cytometry and sorting, 2nd edn. Wiley-Liss, New York

Responsible Subject Editor: W. Körting, Hannover, Germany
Morgan JAW, Pottinger TG, Rippon P (1993) Evaluation of flow cytometry as a method for quantification of circulating blood cell populations in salmonid fish. J Fish Biol 42: $131-141$

Otto F (1990) DAPI staining of fixed cells for high-resolution flow cytometry of nuclear DNA. In: Darzynkiewicz Z, Crissman HA (eds) Methods in cell biology, Vol 33. Academic Press, San Diego, p 105-110

Rowley AF, Hunt TC, Page M, Mainwaring G (1988) Fish. In: Rowley AF, Ratcliffe NA (eds) Vertebrate blood cells. Cambridge University Press, Cambridge, p 19-127

Schreiber A, Schenk M, Lehmann J, Stürenberg FJ (1994) Genetische Untersuchungen an Meerforellen und Lachswildfängen aus dem Rheinsystem in Nordrhein-Westfalen. Fischer Teichwirt 2:52-53

Steinhagen D (1985) Untersuchungen zum Infektionsverlauf von Trypanoplasma borreli Laveran \& Mesnil, $1901 \mathrm{im}$ Karpfen Cyprinus carpio L., 1758 und die Auswirkungen der Infektion auf den Wirtanrganicmus. Dissertation, Iniversität Hannover, Fachbereich Biologie

Steinhagen D, Kruse P, Körting W (1990) Some haematological observations on carp, Cyprinus carpio L., experimentally infected with Trypanoplasma borreli Laveran \& Mesnil, 1901 (Protozoa: Kinetoplastida). J Fish Dis13:157-162

Thorgaard GH, Rabinovitch PS, Shen MW, Gall GA, Propp J, Utter FM (1982) Triploid rainbow trout identified by flow cytometry. Aquaculture 29:305-309

Tiersch TR, Chandler RW, Wachtel SS, Elias S (1989) Reference standards for flow cytometry and application in comparative studies of nuclear DNA content. Cytometry 10: $706-710$

Utter FM, Johnson OW, Thorgaard GH, Rabinovitch PS (1983) Measurement and potential applications of induced triploidy in Pacific salmon. Aquaculture 35:125-135

Woo PTK (1969) The haematocrit centrifuge for the detection of trypanosomes in blood. Can J Zool 47:921-923

Zapata A (1979) Ultrastructural study of the teleost fish kidney. Dev comp Immunol 3:55-65

Manuscript first received: June 15, 1995

Revised version accepted: September 4, 1995 